$14^{\text {th }}$ Conf. Agric. Dev. Res., Fac. Agric., Ain Shams Univ.,

March, 2019., Cairo, Egypt

Special Issue, 27(1), 77 - 82, 2019

Website: http://strategy-plan.asu.edu.eg/AUJASCI/

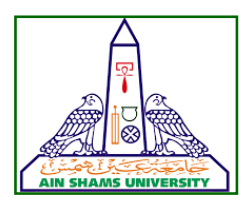

\title{
AUTOMATIC IRRIGATION BY USING SOIL MOISTURE SENSOR IN VERTI- CAL CLOSED SYSTEM FOR LETTUCE PRODUCTION
}

Ayaa, K. Moustafa ${ }^{1}$, U.A. El-Behairy ${ }^{2}$, El-Bagoury ${ }^{1}$, K.F. and El-Gindy ${ }^{1}$, A.M.

1. Agricultural Engineering Dept., Fac. of Agric., Ain Shams Univ., P.O. Box 68-11241 Hadyek Shoubra, Cairo, Egypt

2. Horticulture Dept., Fac. of Agric., Ain Shams Univ., P.O. Box 68 Hadyek Shoubra 11241, Cairo, Egypt

*Corresponding author: ayaa khalil@yahoo.com

Received 15 September, 2018, Accepted 18 September, 2018

\section{ABSTRACT}

The experiment was held at the Arid land Agricultural graduate studies and Research Institute Ain Shams University. A soil moisture sensor is designed and used for measuring and controlling soil moisture content in plant media. The device has been programmed and connected to three water-lifting pumps to operate them according to each treatment.

A vertical system has been constructed using 18 columns of white square styrofoam pots filled with perlite (In-organic substrate). Three soil moisture content treatments were selected as $\mathrm{T}_{1}=60 \%$, $\mathrm{T}_{2}=80 \%$, and $\mathrm{T}_{3}=100 \%$ which were controlled by the sensors. Solution tank filled with dissolved nutrient elements was used for supplying required water.

Two types of lettuce (green and red) lettuce seedlings were planted in the perlite substrate and irrigated by drip irrigation system. The system was closed and was based on smart automatic drip irrigation system,

Results revealed that, 556.5 liters of water was consumed under condition of $\mathrm{T}_{1}=60 \%$, while 697.5 liters and 908.5 were consumed under condition of $\mathrm{T}_{2}=80 \%$, and $\mathrm{T}_{3}=100 \%$ respectively-After 47 days the Red lettuce yield (weight, number of leaves, and also weight of dry lettuce) was higher than green lettuce for all treatments.

Yields of lettuce per system unit $(4.5 \mathrm{~m} 2) 16$ $\mathrm{kg} / \mathrm{m}^{2}$ and water use efficiency $26 \mathrm{~kg} / \mathrm{m}^{3}$ (Barbosa et al 2015) conventional production yielded $3.9 \pm$
$0.21 \mathrm{~kg} / \mathrm{m} 2 / \mathrm{y}$ of lettuce produce, with water. Hydroponics offered $11 \pm 1.7$ times higher yields but required $82 \pm 11$ times more energy compared to conventionally produced lettuce.

Keywords: Agricultural engineering, Soilless culture, Perlite substrate, Soil moisture sensor, Vertical hydroponics

\section{INTRODUCTION}

We have to thinking for solution to increase food production for per area. The global demand for food will increase for at least another 40 years cause of continuing population and consumption growth. Incerasing competition for land, water, and energy, and the overexploitation of fisheries, will affect our ability to produce food, as will the urgent requirement to reduce the impact of the food system on the environment. (Godfray et al 2010).

The sustained growth of the world's population in the coming years requires a greater role for agriculture to meet the food needs of humankind. It is necessary to develop new and affordable sensor technologies for agricultural operations. This type of innovation should be implemented in the context of the consideration of the farm, the crops and the surrounding areas, with a view to providing farmers with the information to make better decisions to boost production To improve the productivity and competitiveness of the agro-industry, (Rosell-Polo et al 2015)

Soilless plants fall in to two primary classes: 1. Liquid Culture where nutrient solution is recirculat- 
ed after re-aeration (true hydroponics) 2. Aggregate Culture where the nutrient solution is supplied to plants Via an irrigation system through the media , and excess solution allowed to run to waste or the solution is recirculated (e.g. perlite, Rockwool, pumice, sand culture, gravel culture etc.).A number of media ( called artificial media or mixtures) have been use as substrates for soilless culture (Olympios , 1992).

Vertical farming systems (VFS) have been proposed as an engineering solution to increase productivity per unit area of cultivated land by extending crop production into the vertical dimension (Touliatos et al 2016).

Selecting the best substrate between the various materials is necessary to plant productivity; different substrates have several materials which could have direct or indirect effects on plant development and growth. (Ghehsareh et al 2012).

Moisture sensors are particularly suitable for irrigation management in greenhouse soilless production. Identifying the practical effects of substrate water content set-points on crop performance is decisive for successful sensor-based irrigation (Montesano et al 2018).
Building a smart irrigation system using Arduino (a microcontroller) and many devices (humidity, temperature, pressure and water flow sensors, to perform better irrigation systems by increasing the precision of measurements but also by automating decisions (Casado et al 2018).

\section{The aim of this research is to study:}

1. The effect of using soil moisture sensor on controlling the water consumption for lettuce.

2- Increase productivity of lettuce per area and unit by using the vertical system and-closed system to control the addition of nutrient solutions..

\section{MATERIAL AND METHODS}

Eighteen columns (1.5 meters height) were installed and providing by water source through a small open conduct ( $120 \mathrm{~cm}$ length \& $20 \mathrm{~cm}$ width). Three underground poly phenyl ethylene solution tank. The tank volume is 100 liters filled) by nutrient solution, each tank was connected to water pump (HQB-3500 Type)

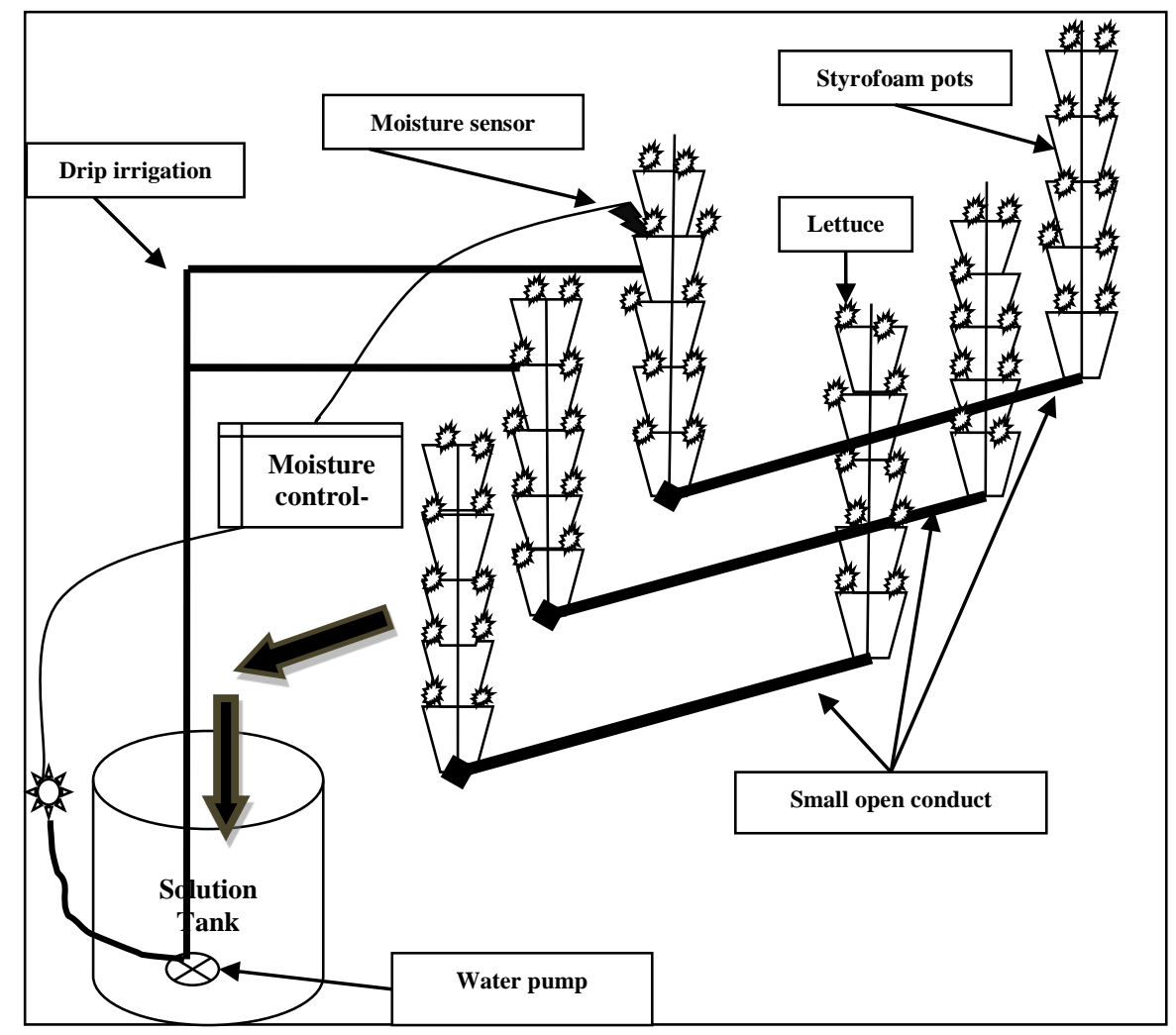

Fig. 1.The automatic vertical closed irrigation system 

lettuce production

The pots were placed in the form of columns supported by a sloping and combined water conduct which is connected to the nutrient solution tank; the pots were filled with the non-organic medium-to-soft perlite substrate, so that aeration and soft spaces were available for long-term nutrient retention and the moisture-sensor readability of moisture readings. The whole system volume was 200 liters of perlite, where the volume of single pot 2 liters of perlite substrate.

\section{1. (Fig.2) Soil moisture sensors}

Three soil moisture sensors were used one for each treatment. The sensor consists of two electrodes working as poles to read the value of the soil moisture_content-by reading the inverse of the electrical resistance, Sensors have been installed in each pots at a depth of about 5 centimeters in contact with the perlite substrate to estimate the value of the moisture content in the perlite

The sensor moisture has been programmed to operate and shut of the pump at the three selected different soil moisture content, T1 $60 \%, \mathrm{~T}_{2} \quad 80 \%$ and $\mathrm{T}_{3} 100 \%$.

The water consumption of the lettuce was measured in the three treatments by using the volume of the nutrient solution tank.

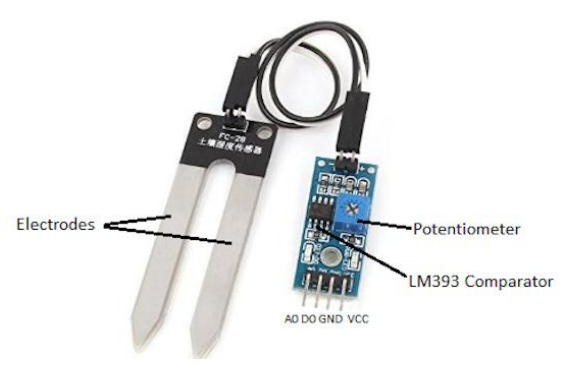

(A) Soil moisture sensor

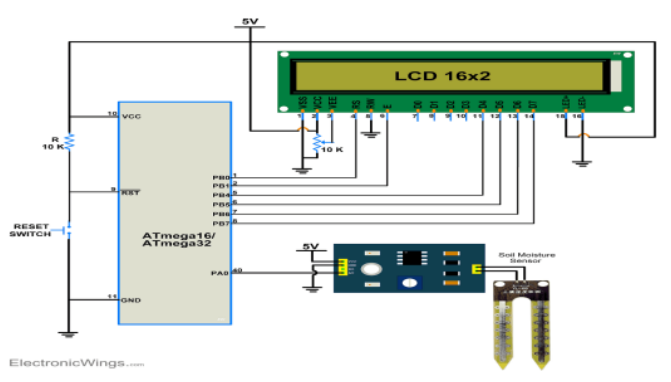

(B) Circuit Diagram of Soil Moisture Sensor

Fig (A, B). Soil moisture and circuit diagram

\section{Irrigation}

Drip irrigation was used in the system two micro drip tube supply water to each column, one at the top of the column and the second in the middle. Below every Styrofoam pot 4 holes for the nutritious solution closed cycle.

Each irrigation treatment has a special moisture sensor which was connected to the controller of its water pump inside the solution tank.

\section{Agricultural shade nets cover}

Agricultural shade nets was used to protect the plants from cold and wind, block insects and prevent spread of disease, and overheating; $200 \mathrm{mi}$ crons thickness White on black Plastic mulch films was used to cover the water conduct.

Daily measurements were made of $\mathrm{pH}(\mathrm{pH}$ meter) and EC (portable conductivity meter) in the nutrient solution tank, $\mathrm{pH}$ and conductivity are analyzed on laboratory, and the nutrient solution concentration is adjusted manually.

\section{Lettuce planting}

In the lab of the (ALARI), the red lettuce and green lettuce plants (the vegetative growth and the roots,). Were weighted and dried in an oven at $70^{\circ} \mathrm{C}$ for 48 to 72 hour until weights reached constant value then the dried plants were weighed and the dry weight per plant was calculated.

The lettuce seedlings was planted at October 13, 2016 and harvested at November 28, 2016, growth period. The total water consumption during the 47 days the growth period was measured and calculated for the three soil moisture content treatments $T_{1}, T_{2} \& T_{3}$

\section{Calculation of water consumption}

Automatic water supply tanks were individually mounted for each plot using a PVC pipe of 200 $\mathrm{mm}$ of diameter. This system permits the automatic water inflow to the nutrient solution reservoir by means of a ball-cock valve, keeping a constant volume. Supply tank was equipped with a ruler set up to the side of a transparent micro-tube that allows for the calculation of water consumed pre plant.

$$
V_{E T C}=\frac{(L f-L i) \times \pi \times D^{2}}{4 \times n \times \Delta T}
$$


Where: $\mathrm{VETC}=$ water consumption, $\mathrm{m} 3$ plant-1 day-1; Lf = current height of water in the tank, $\mathrm{m}$; $\mathrm{Li}$ $=$ initial height of water in the tank, $\mathrm{m} ; \mathrm{D}=$ reservoir internal diameter, $\mathrm{m} ; \Delta \mathrm{T}=$ time interval between the measurements, day; $n=$ number of plants per gully (Soares et al 2018).

\section{RESULTS AND DISCUSSION}

Results revealed as shown in Fig. 3 \& Fig. 4 that, 556.5 liters of water was consumed under condition of $\mathrm{T}_{1}=60 \%$, while 697.5 liters and 908.5 were consumed under condition of $\mathrm{T}_{2}=80 \%$, and $\mathrm{T}_{3}=$ $100 \%$ respectively. It is clear that the highest water consumption was under the condition of $T_{3} 100 \%$ moisture content. The water consumption increased with the time and decreased before the harvest.

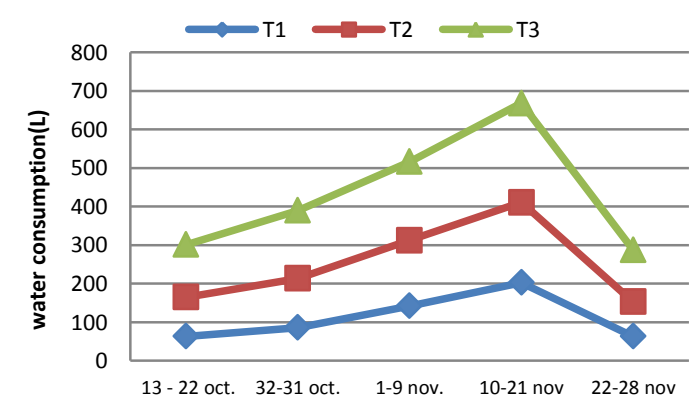

Fig. 3. Water consumption for lettuce during growth period

\section{Water quantities}

We used this method for calculate water consumption by Noted the height of water in the tank solutions, as Fig. (4) shows T1 water consumption/ season was 556.5 liters \& T2 was 697.5 liters and T3 consumed 908.5 liters of water / season

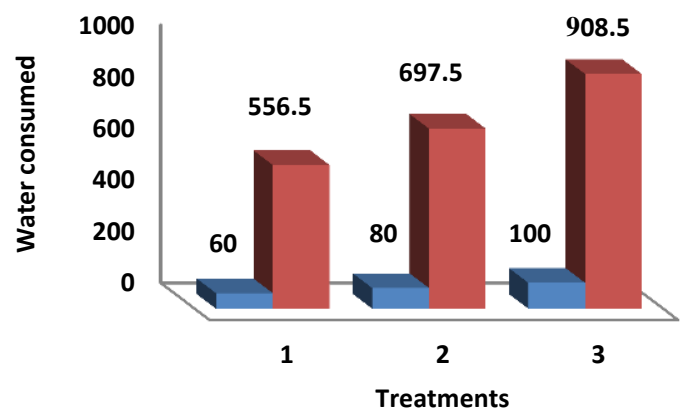

Fig. 4. Total amount of water consumed

\section{Yield fresh weight per plant}

In this table shows two indicators of growth for the case of lettuce the first indicator is vegetative growth and this is the part of the upper vegetative part of which the efficiency of water consumption is calculated.

The second indicator is the sum of the vegetative portion and the fresh roots in grams and this indicator is used to calculate productivity in the area unit

Table 1. Productivity of green and red lettuce under three treatments

\begin{tabular}{|l|c|c|c|c|c|c|}
\hline \multirow{2}{*}{ Treatments } & \multicolumn{2}{|c|}{$T(1)(60 \%)$} & \multicolumn{2}{c|}{$T(2)(80 \%)$} & \multicolumn{2}{c|}{$T(3)(100 \%)$} \\
\cline { 2 - 6 } & $\begin{array}{c}\text { Green } \\
\text { Lettuce }\end{array}$ & $\begin{array}{c}\text { Red } \\
\text { Lettuce }\end{array}$ & $\begin{array}{c}\text { Green } \\
\text { Lettuce }\end{array}$ & $\begin{array}{c}\text { Red } \\
\text { Lettuce }\end{array}$ & $\begin{array}{c}\text { Green } \\
\text { Lettuce }\end{array}$ & $\begin{array}{c}\text { Red } \\
\text { Lettuce }\end{array}$ \\
\hline Water consumed lit/season & \multicolumn{2}{|c|}{556.5} & \multicolumn{2}{c|}{697.5} & \multicolumn{2}{c|}{908.5} \\
\hline Vegetative growth $(\mathrm{kg})$ & 8.197 & 9.33 & 9.00 & 9.68 & 8.39 & 11.16 \\
\hline Total growth (kg) & 11.243 & 13.421 & 12.330 & 14.07 & 8.997 & 11.940 \\
\hline Water use Efficiency $\left(\mathrm{kg} / \mathrm{m}^{3}\right)$ & \multicolumn{3}{|c|}{31.499} & \multicolumn{2}{|c|}{26.759} & 21.521 \\
\hline
\end{tabular}

\section{Yield per meter square}

The treatment area was about $1.5 \mathrm{~m}^{2}$. and the best treatment was the $\mathrm{T}(2)$ at $80 \%$ water content $17.6 \mathrm{~kg} / \mathrm{m}^{2}$ productivity, $\mathrm{T}(1)$ at $60 \%$ was 16.44 $\mathrm{kg} / \mathrm{m}^{2}$ and the less productive was T (3) at $100 \%$ water content $13.96 \mathrm{~kg} / \mathrm{m}^{2}$, which is due to the fact that the percentage of the water content of the perlite substrate reflects the absence of air spaces The observation in this treatment is that the weakness is weak and there is a elongation of lettuce leaves and the number of lettuce leaves was few.

From table. 1 the total growth of both the production of red and green lettuce was calculated and the results were given that the treatment (1) was $24.66 \mathrm{~kg}$ productivity and the treatment (2) 

lettuce production

was $26.40 \mathrm{~kg}$ and the treatment (3) was given the less production which it was $20.93 \mathrm{~kg}$.

Table 2. Productivity for area

\begin{tabular}{|l|c|c|c|}
\hline & T1 & T2 & T3 \\
\hline total growth $(\mathrm{kg})$ & 24.66 & 26.40 & 20.93 \\
Productivity/area (kg/m2) & 16.44 & 17.6 & 13.96 \\
\hline
\end{tabular}

4. Water use efficiency for each treatment (Fig. 5)

The best treatment was the $\mathrm{T} 1$ where it achieved the highest efficiency for water ore 31.5 $\mathrm{g} / \mathrm{L}$ and comes in second place T 2 where the efficiency of water use $26.75 \mathrm{~g} / \mathrm{L}$ and finally the treatment 3 achieved $21.52 \mathrm{~g} / \mathrm{L}$

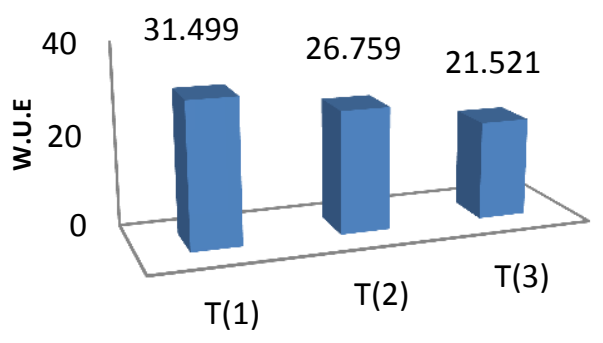

Fig. 5. Water use efficiency for three treatments

\section{REFERANCE}

Barbosa, G.L., Gadelha, F.D.A., Kublik, N., Proctor, A., Reichelm, L., Weissinger, E. and Halden, R.U. 2015. Comparison of land, water, and energy requirements of lettuce grown using hydroponic vs. conventional agricultural methods. International Journal of Environmental Research and Public health, 12(6), 6879-6891.
Casado, C. G., Cisquella, M.L. and López, S. A. 2018. Intelligent Irrigation System Based on Arduino. arXiv preprint arXiv:13(2), 217-219.

Ghehsareh, A.M., Hematian, M. and Kalbasi, M. 2012. Comparison of date-palm wastes and perlite as cure substrates on growing indices in greenhouse cucumber. International Journal of Recycling of Organic Waste in Agriculture, 1(1), 5-9

Godfray, H.C.J., Beddington, J.R., Crute, I.R., Haddad, L., Lawrence, D., Muir, J. F., and Toulmin, C. 2010. Food security: the challenge of feeding 9 billion people. Science, 15(5) 98114.

Montesano, F.F., van lersel, M.W., Boari, F., Cantore, V., D'Amato, G. and Parente, A. 2018. Sensor-based irrigation management of soilless basil using a new smart irrigation system: Effects of set-point on plant physiological responses and crop performance. Agricultural Water Management, 203(24), 20-29.

Olympios, C.M. 1992, March. Soilless media under protected cultivation rockwool, peat, perlite and other substrates. In Symposium on Soil and Soilless Media under Protected Cultivation in Mild Winter Climates 323(7), 215-234.

Rosell-Polo, J.R., Cheein, F.A., Gregorio, E., Andujar, D., Puigdomènech, L., and Masip, J. 2015. Advances in structured light sensors applications in precision agriculture and livestock farming. Advances in Agronomy 22 (133), 71-112.

Soares, T.M., Duarte, S.N., de França, Ê.F., Mélo, R.F., de Andrade Jorge, C. and de Oliveira, Á.S. 2018. Experimental structure for evaluation of brackish water use in lettuce hydroponic production. Irriga, 14(1), 102-114.

Touliatos, D., Dodd, I.C. and McAinsh, M. 2016. Vertical farming increases lettuce yield per unit area compared to conventional horizontal hydroponics. Food and energy Security, 5(3), 184-191. 

الري الاتوماتيكي بإستخدام مستشعر الرطوية للترية فى النظام الرأسي لإنتاج الخس

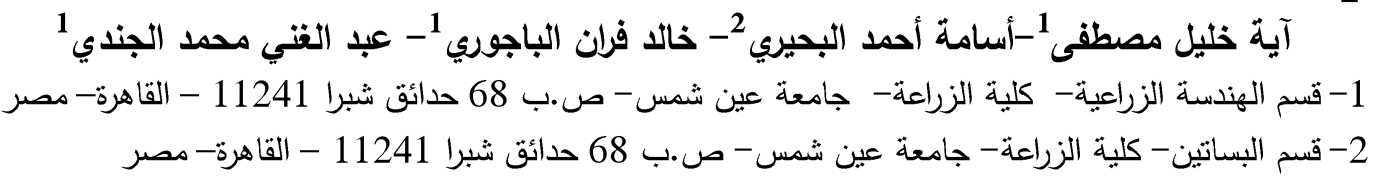

"Corresponding author: ayaa khalil@yahoo.com

Received 15 September, 2018, Accepted 18 September, 2018

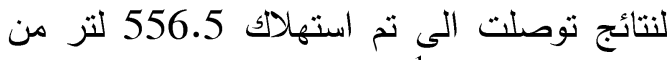
المياه تحت المعامله م⿸广

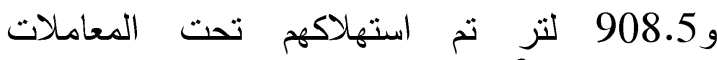

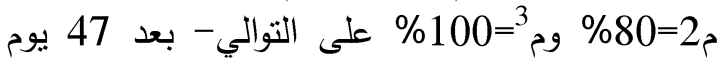

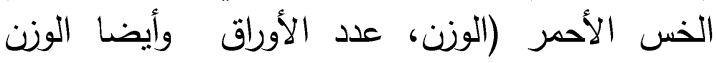
الجاف (كان أعلى من الخس الأنس الأخضر في جميع كان إنتاج الخس بنسبة لوحدة النظام (4.5 م²) 16

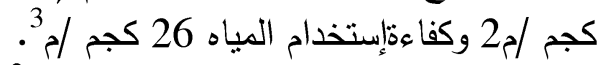

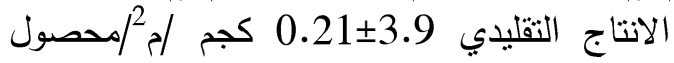

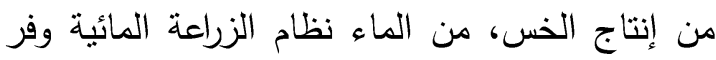

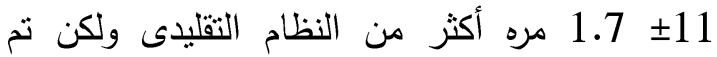
استهلالى 11 82 11 مره من الطاقه أعلى من أنتاج (Barbosa et al الخس مقارنة بالطرق التقليدية 2015)

الكلمات الدالة: هندسة زراعية، زراعة بدون تربة، بية التربة

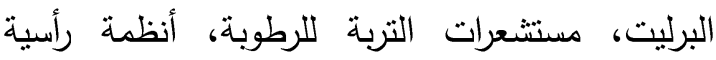

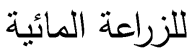

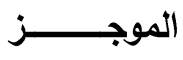

أقيمت التجربة فى معهد الدراسات العليا للأراضي

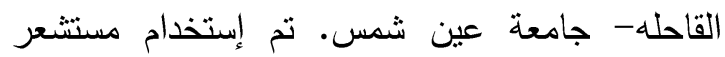
التربة للرطوبة حتى يقيس ويتحكم في محتوى رطوبة فئة التربة فى بيئة النبات ،تم بلته برمجة الجهاز وتوصيله

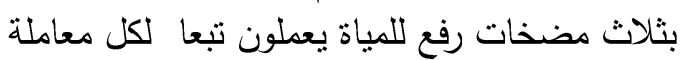

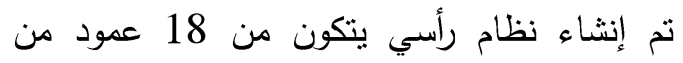
بوتسات بيضاء مصنوعة من الفوم ومملوهة بيئة

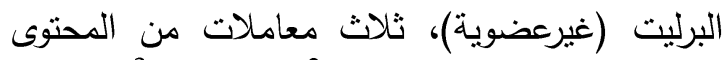

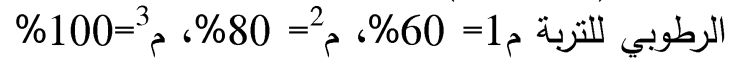
حيث كانت متحكم فيها عن طريق المستشعرات، حاوية ماته

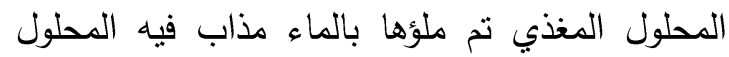
المغذي وكانت هى التى تمد النظام بالاحتياج المائي

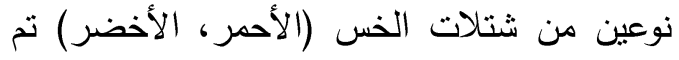
زراعتهم في بيئة البرليت وتم ريهم بنظام الري بالتنقيط. النظام ري ذكي مغلق اتوماتيكى بنظام التتقيط 